\title{
DDX6 wt Allele
}

National Cancer Institute

\section{Source}

National Cancer Institute. DDX6 wt Allele. NCI Thesaurus. Code C49407.

Human DDX6 wild-type allele is located in the vicinity of $11 \mathrm{q} 23.3$ and is approximately 41 $\mathrm{kb}$ in length. This allele, which encodes probable ATP-dependent RNA helicase DDX6 protein, plays a putative role in mRNA decapping during the process of mRNA degradation. The DDX6 gene is associated with several types of cancer including B-cell lymphomas and colorectal adenocarcinomas. 